Yu.V. Sukhatskiy, Z.O. Znak, O.I. Zin

\title{
CAVITATION AND ITS COMBINATIONS WITH OTHER ADVANCED OXIDATION PROCESSES IN PHENOL WASTEWATER TREATMENT: A REVIEW
}

\author{
Lviv Polytechnic National University, Lviv, Ukraine
}

\begin{abstract}
The review provides a systematic understanding of the mechanism of the sonochemical degradation of phenol. It was shown that the main contribution to the sonochemical degradation of phenol, a hydrophilic non-volatile wastewater component, is related to hydroxylation on the boundary of the «cavitation bubble-water contaminant solution». Depending on the method of generating hydroxyl radicals, all wastewater treatment methods for phenol removal based on advanced oxidation processes are classified into the following categories: chemical (acoustic and hydrodynamic cavitation, use of oxidants, Fenton process, and Fenton-like processes), photochemical (photolysis and photocatalysis), electrochemical and combined techniques. The essence of these methods is revealed and their main advantages and disadvantages are reviewed. It is shown that the efficiency of combined methods of phenol degradation that are based on the use of cavitation (acoustic or hydrodynamic) depends on the power of ultrasonic emitters, the frequency of ultrasonic vibrations, the magnitude of the pressure at the inlet of the hydrodynamic cavitator, physicochemical properties of media (temperature and $\mathrm{pH}$ ), initial phenol concentration in aqueous medium, the design features of the cavitation generators, the presence of water-soluble gases or solid particles that exhibit catalytic properties, and the consumption of oxidizing reagents. Literature data showed that the most cost-effective method involving the use of ultrasonic cavitation is a combination «ultrasonic cavitation+photolysis+ozonation». The choice of a particular method for the degradation of phenol is determined by its content in wastewaters and their volume, the required degree of degradation, the duration of the purification process (the rate of degradation of the phenol), and economic indicators.
\end{abstract}

Keywords: cavitation, phenol, hydroxyl radicals, ultrasound, Fenton process, photolysis, photocatalysis.

DOI: $10.32434 / 0321-4095-2020-131-4-16-30$

\section{Introduction}

Phenol and its derivatives are used as preservatives for paints, leather and textiles [1] as well as intermediates in the production of phenolformaldehyde resins, synthetic fibers (for example, nylon), polymers (caprolactam), and for the synthesis of epoxy precursor compounds (for example, bisphenol A) [2,3]. Phenol is also a main starting material for the production in the following industries: pharmaceutical, metallurgical, paint and varnish, pulp and paper, textile, cosmetic [4-8], etc. In agriculture, phenol and its derivatives are actively used as pesticides, herbicides and fungicides $[9,10]$. In medicine, it is used as an antibacterial agent, local anesthetic or antiseptic [7]. Phenol is an integral component of the wastewater of the chemical, petrochemical and coke-chemical industries [11$16]$.

Phenol content in industrial wastewater varies within very wide limits [15] $\left(\mathrm{mg} \mathrm{dm}^{-3}\right): 6-500$ in oil refineries; $28-3900$ in coke production facilities; 96800 in coal plants; $2.8-1220$ in petrochemical enterprises; and 0.1-1600 in pharmaceutical, polymer, paint, pulp and paper industries, and wood processing companies.

Even low concentrations of phenol is highly toxic $[4,5,8,13,15,16]$, it reveals carcinogenic, mutagenic and teratogenic properties $[3,4,10]$. Shortterm effects of phenol on humans and animals result in irritation of the skin, eyes, respiratory organs,

(C) Yu.V. Sukhatskiy, Z.O. Znak, O.I. Zin, 2020

Yu.V. Sukhatskiy, Z.O. Znak, O.I. Zin 
headache; long-term effects causes anemia, liver damage, kidney damage, paralysis, and lung cancer $[4,7,10]$. Due to its high toxicity, phenol has a low potential for biodegradation [16]. Therefore, methods based on the use of cavitation or other advanced oxidation processes (treatment with hydrogen peroxide, ozone, Fenton processes, photolysis, photocatalysis, and electrochemical oxidation) as well as their combinations show excellent prospects for wastewater treatment from phenol. In view of the above, the purpose of this review is to systematize theoretical ideas about the mechanism of sonochemical degradation of phenol as well as analyze the effectiveness of various methods of wastewater treatment of phenol in order to choose the best ones to develop new efficient technological processes.

\section{phenol}

Mechanism of sonochemical degradation of

There are two main mechanisms of sonochemical degradation of organic pollutants [1719]: (i) thermal pyrolysis, and (ii) radical one (hydroxylation). The mechanism of sonochemical degradation depends on the chemical nature and physicochemical properties of the organic compound. Commonly, the degradation of organic substances occurs simultaneously via two mechanisms, with a significant predominance of one of them. Thus, the sonochemical degradation of volatile hydrophobic organic compounds is mainly due to thermal pyrolysis inside the cavitation bubble during its collapse, and the dominant contribution to the sonochemical degradation of non-volatile hydrophilic components is hydroxylation [20].

Phenol is a non-volatile hydrophilic component of wastewater, and therefore the major contribution to its degradation is determined by its interaction with hydroxyl radicals. Hydroxylation is described by the following scheme [3]:

$\mathrm{C}_{6} \mathrm{H}_{5} \mathrm{OH}+{ }^{\circ} \mathrm{OH} \rightarrow \mathrm{C}_{6} \mathrm{H}_{4}(\mathrm{OH})_{2}$ (o-, p-isomers) +

$+\mathrm{C}_{6} \mathrm{H}_{4} \mathrm{O}_{2}$ (p-isomer) $\rightarrow \mathrm{CO}_{2}+\mathrm{H}_{2} \mathrm{O}$,

that is, the intermediates of sonochemical degradation of phenol are 1,2-dihydroxybenzene, 1,4-dihydroxybenzene and 1,4-benzoquinone. These intermediates were detected in the case of ultrasonic (US) treatment (US radiation frequency of $20 \mathrm{kHz}$ and specific power of $50 \mathrm{~W} / \mathrm{cm}^{2}$ ) of phenol at a $\mathrm{pH}$ 3.0 and an initial phenol concentration of 30 to $70 \mu \mathrm{mol} / \mathrm{dm}^{3}$. In the studies of sonochemical degradation of phenol at $\mathrm{pH}$ of 5.4 to 5.7 , only 1,2-dihydroxybenzene and 1,4-dihydroxybenzene were detected, and no intermediate formation was observed at $\mathrm{pH} 12.0$ [21]. 1,3-dihydroxybenzene is also considered as possible intermediate [9].

The final products of the sonochemical degradation of phenol, depending on the treatment conditions, may be organic acids (e.g. maleic and oxalic acids) $[4,15,16,22-25]$ or even $\mathrm{CO}_{2}$ and $\mathrm{H}_{2} \mathrm{O}$.

Methods of purification of wastewater from phenol

An important role in the oxidation of organic matter plays hydroxyl radicals [26]. The oxidation processes that occur with their participation are called advanced oxidation processes. Depending on the method of generating hydroxyl radicals [7], all purification methods based on advanced oxidation processes are divided into chemical (acoustic and hydrodynamic cavitation, use of oxidants; Fenton process and Fenton-like processes), photochemical (photolysis and photocatalysis), electrochemical and combined processes.

Traditional physicochemical (for example, adsorption) and biological methods are ineffective for phenol degradation and therefore they are not used as stand-alone methods, but only in combination with others.

\section{Chemical methods \\ Cavitation}

Cavitation refers to the appearance, growth and flattening of cavitation bubbles at large gradients of temperature (up to $10^{4} \mathrm{~K}$ ) and pressure (up to $10^{2} \mathrm{MPa}$ ), which causes the sonolysis of water with the formation of hydroxyl radicals:

$$
\begin{aligned}
& \mathrm{H}_{2} \mathrm{O} \rightarrow \mathrm{H}^{\bullet}+{ }^{\bullet} \mathrm{OH} \\
& \mathrm{O}_{2} \rightarrow 2 \mathrm{O}^{\bullet} \\
& \mathrm{H}^{\bullet}+\mathrm{O}_{2} \leftrightarrow{ }^{\bullet} \mathrm{O}^{\bullet}+{ }^{\bullet} \mathrm{OH} \\
& \mathrm{O}^{\bullet}+\mathrm{H}_{2} \mathrm{O} \leftrightarrow 2^{\bullet} \mathrm{OH}
\end{aligned}
$$

The mechanism of cavitation sonolysis of water was described in detail in studies [26,27].

There are two main types of cavitation: acoustic (caused by the influence of the ultrasonic waves of the ultrasonic range on the water) and hydrodynamic (caused by the local decrease of the pressure in the liquid to the values of the saturated water vapor pressure due to a sharp change in the flow rate of the fluid, depending on the geometry of the system). However, regardless of the type of cavitation, the degradation efficiency of phenol as a hydroxy derivative of benzene $[28,29]$ will be determined by a number of factors: the power of ultrasonic emitters $[10,30,31]$, the magnitude of the pressure at the inlet of the hydrodynamic cavitator [15,32], the frequency 
of ultrasonic $[1,3,5,22,25]$, the physicochemical properties of media (temperature and $\mathrm{pH}$ ) $[1,33,34]$, the initial phenol concentration in aqueous medium $[1,15,30]$, and the design features of cavitation generators $[15,16,35-40]$.

It was established that an increase in power of ultrasonic emitters is effective only up to a certain limit $(\sim 200 \mathrm{~W})[10]$. A further increase in the power of ultrasound generators causes an increase in the concentration of bubbles per unit volume of the medium, which complicates their collapse and accordingly the cavitation transformation of phenol.

It was found that the optimal value of the pressure at the inlet of the hydrodynamic cavitator, at which maximum phenol degradation was achieved, was $\sim 0.5 \mathrm{MPa}[15,32]$.

Optimal values of the frequency of ultrasound radiation for cavitational degradation of phenol were in the range of 200 to $300 \mathrm{kHz}[1,3,5,22,25]$. Cavitational treatment of aqueous media by US radiation at these frequencies provides the maximum concentration of hydroxyl radicals in aqueous solutions. Effective multifrequency cavitation reactors are currently used for degradation of organic compounds [30].

The temperature range for the effective cavitation degradation of phenol is $303-308 \mathrm{~K}$ $[33,34]$. The acidic medium contributes to the increase in the degree of phenol conversion $[1,33,34]$, which explains a higher likelihood of the phenol approaching the interface «surface of the cavitation bubble-aqueous solution», where the concentration of radicals is the highest.

An increase in the initial concentration of the pollutant (phenol) was found to cause a decrease in the rate constant of its sonochemical degradation $[1,15,30]$ at a constant power of the cavitation generator. Under these conditions, the release of the decomposition products of water involved in the oxidation of phenol is constant. Accordingly, as the concentration of phenol increases, the ratio of its concentration to the concentration of the decomposition products of water increases and the rate of its transformation decreases.

As for the influence of the design features of cavitation generators (type, size, number and arrangement of cavitation elements) [15,16,35-40] on the efficiency of cavitation degradation of phenol, it will depend on the intensity of hydroxyl radical generation in a particular cavitation reactor.

The degradation efficiency of phenol can be significantly enhanced by the introduction of gases $[1,24,30,37,41,42]$ or solid particles (inorganic oxides, usually oxides of d-elements and salts) $[1-3,17,24,43]$ into an aqueous medium; they act as cavitation embryos or decomposition catalysts formed by cavitation treatment of aqueous hydrogen peroxide solutions with the release of hydroxyl radicals involved in the degradation processes of organic compounds.

It is known that the collapse temperature is higher for monoatomic gas bubbles, such as argon due to its lower heat capacity than for diatomic gas bubbles (air, oxygen, and nitrogen). Therefore, the generation of radicals from the cavitation collapse of monoatomic gas bubbles is much more intense. However, oxygen dissolved in water can effectively store the radicals [42] that fall into the liquid due to the flattening of the cavitation bubble (reactions (4) and (5)).

It was found that the rate of degradation of phenol and the rate of formation of oxidants (hydrogen peroxide due to recombination of hydroxyl radicals) decrease in the following series: $\mathrm{O}_{2}>$ air $>\mathrm{He}$, $\mathrm{N}_{2}$ [24]. An increase in gas consumption by 5 times (from 0.05 to $0.27 \mathrm{dm}^{3} / \mathrm{min}$ ) also leads to an increase in the degree of cavitation degradation of phenol (pressure at the inlet of the cavitator of $0.2 \mathrm{MPa}$ and treatment duration of $90 \mathrm{~min}$ ): from 16.3 to $21 \%$ and from 26.3 to $27.6 \%$ for $\mathrm{N}_{2}$ and $\mathrm{O}_{2}$, respectively [37].

It was established that the cavitation degradation efficiency of phenol (duration of treatment of $90 \mathrm{~min}$ ) is higher in the case of using air than argon irrespective of the frequency of ultrasonic radiation and the $\mathrm{pH}$ of the medium at the gas flow rate of $1.5 \mathrm{dm}^{3} / \mathrm{min}$ for an aqueous solution of phenol with a concentration of $5 \mathrm{mmol} / \mathrm{dm}^{3}$ [1]. The research was carried out with wastewater, the volume of which was 80,100 and $300 \mathrm{~cm}^{3}$. Thus, at the frequency of ultrasonic radiation of $300 \mathrm{kHz}$ and $\mathrm{pH}$ of 5.6 , the degradation efficiency of phenol was $(\mathrm{mmol} / \mathrm{W})$ : $1.69 \cdot 10^{-2}$ and $1.61 \cdot 10^{-2}$ for air intake and for introduction of argon, respectively. Reducing the $\mathrm{pH}$ to 2.0 at a constant ultrasound frequency $(300 \mathrm{kHz})$ contributed to an increase in the degradation efficiency of phenol (mmol/W): $2.34 \cdot 10^{-2}$ and $2.04 \cdot 10^{-2}$ for air intake and for argon, respectively. For ultrasound frequencies of $520 \mathrm{kHz}$ and a $\mathrm{pH}$ of 5.6, the cavitation degradation efficiency of phenol was equal to (mmol/W): $1.37 \cdot 10^{-2}$ and $1.15 \cdot 10^{-2}$ for air intake and introduction of argon, respectively. At $\mathrm{pH} 2.0$ and a constant US frequency $(520 \mathrm{kHz})$, the degradation efficiency of phenol was higher than at pH $5.6(\mathrm{mmol} / \mathrm{W}): 1.79 \cdot 10^{-2}$ and $1.61 \cdot 10^{-2}$ for air intake and for argon input, respectively. The higher efficiency of cavitation phenol degradation in the presence of air bubbles in the aqueous medium is due to the reactions of nitrogen with molecular 
oxygen to produce nitric acid and radicals $\left({ }^{\circ} \mathrm{OH}\right.$, $\mathrm{NO}_{2}$, and $\mathrm{NO}_{3}$ ) [1], which intensify the oxidation processes of organic compounds as follows:

$$
\begin{aligned}
& 2 \mathrm{~N}_{2}+\mathrm{O}_{2} \rightarrow 2 \mathrm{~N}_{2} \mathrm{O} \\
& \cdot \mathrm{H}+\mathrm{N}_{2} \mathrm{O} \rightarrow \mathrm{N}_{2}+\cdot \mathrm{OH} \\
& \cdot \mathrm{OH}+\mathrm{N}_{2} \mathrm{O} \rightarrow 2 \mathrm{NO}+\cdot \mathrm{H}, \\
& \mathrm{HNO}_{2}+\mathrm{H}_{2} \mathrm{O}_{2} \rightarrow \mathrm{HNO}_{3}+\mathrm{H}_{2} \mathrm{O}, \\
& \mathrm{HNO}_{3} \rightarrow \cdot \mathrm{NO}_{2}+\cdot \mathrm{OH} \\
& \mathrm{HNO}_{3} \rightarrow \cdot \mathrm{NO}_{3}+\cdot \mathrm{H} .
\end{aligned}
$$

Coal ash, which is a waste of thermal power plants, was used as a catalyst for the processes of water sonolysis and cavitation degradation of phenol [2]. The ash contained particles ranging in size from 53 to $106 \mu \mathrm{m}$ and consisted of the following oxides: $\mathrm{SiO}_{2}, \mathrm{Al}_{2} \mathrm{O}_{3}, \mathrm{Fe}_{2} \mathrm{O}_{3}$, and $\mathrm{CaO}$. The treatment of an aqueous solution of phenol by $60 \mathrm{~min}$ ultrasonic radiation (frequency of $200 \mathrm{kHz}$ ) in the presence of 0.5 wt.\% coal ash increased the rate of phenol degradation by $21 \%$ (from $69 \%$ to $90 \%$ ). Implementation of the process in a tert-butanol environment reduced the degradation rate to $20 \%$. This is due to the fact that tert-butanol served as a trap for radicals.

An increase in the efficiency of cavitation degradation of phenol was also observed in the presence of $\mathrm{MnO}_{2}$ or $\mathrm{Fe}^{2+}$ ions in the solution [24].

The catalytic activity of $\mathrm{Al}_{2} \mathrm{O}_{3}, \mathrm{ZnO}, \mathrm{Ni}_{2} \mathrm{O}_{3}$ and $\mathrm{CuO}$ was investigated during ultrasonic treatment (frequency of $520 \mathrm{kHz}$ and treatment duration of $45 \mathrm{~min}$ ) of an aqueous solution of hydrogen peroxide as a source of hydroxyl radicals for oxidation of phenol under isothermal conditions (temperature of $302.5 \mathrm{~K})$. The stirring intensity of the reaction medium was $500 \mathrm{rpm}$. The degradation constant of peroxide hydrogen was stated to decrease in the following series $\mathrm{CuO}>\mathrm{Ni}_{2} \mathrm{O}_{3}>\mathrm{ZnO}>\mathrm{Al}_{2} \mathrm{O}_{3}$ [43].

The addition of sodium chloride (4 wt.\%) to an aqueous solution of phenol led to an increase in the interphase concentration of phenol at the boundary "cavitation bubble-solution», and consequently to an increase in the partial pressure of phenol by three times. Accordingly, there is an increase in the magnitude of the diffusion flux, the probability of entrapment of phenol and its penetration into the bubble, where the mechanism of pyrolysis of pollutants prevails. Thus, the efficiency of cavitation degradation of phenol (at the frequency of ultrasounds of $20 \mathrm{kHz}$ ) increased by more than 3 times (from 1.8 to $6.3 \%$ ) in the presence of sodium chloride in aqueous solution (4 wt.\%) [17].

The main advantages of using acoustic and hydrodynamic cavitation for phenol degradation are the high rate of the process and the low probability of sediment formation. The disadvantages are the high cost and difficulties in industrial scaling of acoustic cavitation due to its unevenness.

Use of oxidizing agents

Hydrogen peroxide [41,44], ozone [16,41], peroxone [45], peroxodisulfates [46], Fenton's reagent and Fenton-like systems [47-53] can be used as oxidizing agents for phenol degradation.

Use of hydrogen peroxide

As a rule, solutions of hydrogen peroxide with a concentration of not less than $30 \mathrm{wt} . \%$ are used for the degradation of organic compounds [41]. In order to achieve high treatment efficiency, intensive mixing and long contact time of peroxide hydrogen with sewage containing organic pollutants must be ensured. It was found that the treatment of an aqueous solution of phenol $\left(10 \mathrm{mg} / \mathrm{dm}^{3}\right)$ during one hour with a $30 \%$ hydrogen peroxide solution at $\mathrm{pH}$ 3.0 made it possible to achieve $84.8 \%$ phenol degradation rate [44].

Use of ozone

Ozone is a powerful oxidant $\left(\mathrm{E}^{0}=+2.07 \mathrm{~V}\right)$, which readily interacts with substances containing double bonds $(C=C, C=N, N=N)$ [41]. High partial ozone pressure, long duration and contact area of ozone with an aqueous pollutant and intensive mixing contribute to the effective degradation of phenol. It is revealed that the ozone supply (at ozone consumption of $35 \mathrm{~cm}^{3} / \mathrm{s}$ ) within 2 hours in an aqueous solution of phenol (the volume was $550 \mathrm{~cm}^{3}$ ) with a concentration of $113 \mathrm{mg} / \mathrm{dm}^{3}$ allowed reaching the degree of degradation of $97 \%$ [16].

Sometimes, the combined $\mathrm{O}_{3} / \mathrm{H}_{2} \mathrm{O}_{2}$ (peroxon) [45] oxidant and peroxodisulfate [46] are used for the degradation of organic compounds.

Application of Fenton process and Fenton-like systems

In advanced oxidation processes, hydrogen peroxide is considered as a source of hydroxyl radicals [47]. The catalyst for the decomposition of hydrogen peroxide is iron ions (Fenton process) [48]:

$$
\begin{aligned}
& \mathrm{Fe}^{2+}+\mathrm{H}_{2} \mathrm{O}_{2} \rightarrow \mathrm{Fe}^{3+}+\mathrm{OH}^{-}+{ }^{\circ} \mathrm{OH} \\
& \mathrm{Fe}^{3+}+\mathrm{H}_{2} \mathrm{O}_{2} \rightarrow \mathrm{Fe}^{2+}+\mathrm{HO}_{2}^{\bullet}+\mathrm{H}^{+} \\
& \mathrm{Fe}^{3+}+\mathrm{HO}_{2}^{\cdot} \rightarrow \mathrm{Fe}^{2+}+\mathrm{O}_{2}+\mathrm{H}^{+}
\end{aligned}
$$


It is believed that aquatic and organocomplexes of iron can be oxidants of organic compounds in addition to hydroxyl radicals [41].

The optimum working $\mathrm{pH}$ value for the implementation of the Fenton process is about 3.0. At lower $\mathrm{pH}$ values $(\mathrm{pH}<2.5)$, the formation of a complex cation $\left[\mathrm{Fe}\left(\mathrm{H}_{2} \mathrm{O}\right)_{6}\right]^{2+}$ occurs, which interacts more slowly with hydrogen peroxide than the $\mathrm{Fe}^{2+}$ ions, and therefore the rate of hydroxyl radical generation and, accordingly, degradation of phenol will be lower. At $\mathrm{pH}>4.0$, the formation of ferric (II, III) hydroxides may take place, which slows down the regeneration of iron ions. In addition, the oxidation potential of hydroxyl radicals decreases with increasing $\mathrm{pH}$. Usually, a mass ratio of $\mathrm{Fe}^{2+}: \mathrm{H}_{2} \mathrm{O}_{2}=1: 5$ is optimal for the degradation of organic compounds, and the range of optimal temperature values is $303-313 \mathrm{~K}$ [41].

Fenton-like systems are known that imply the use of $\mathrm{Fe}^{0}, \mathrm{Cu}^{0}, \mathrm{Ni}^{0}$ [49], iron-containing minerals (schwertmannite) [50], composite iron-containing mesostructured materials (Fe-SBA-15, $\mathrm{Fe}_{2} \mathrm{O}_{3}$-SBA-15) [51,52], a complex of iron-ethylenediaminetetraacetic acid (EDTA) - [ $\left.\mathrm{Fe}^{\mathrm{IV}} \mathrm{O}\right]$ EDTA [53]. In Fenton-like systems, $\mathrm{Fe}^{0}$ is transformed into $\mathrm{Fe}^{2+}$ ions by the following reactions [53]:

$$
\begin{aligned}
& \mathrm{Fe}^{0}+2 \mathrm{H}^{+} \rightarrow \mathrm{Fe}^{2+}+\mathrm{H}_{2}, \\
& \mathrm{Fe}^{0}+\mathrm{O}_{2}+2 \mathrm{H}^{+} \rightarrow \mathrm{Fe}^{2+}+\mathrm{H}_{2} \mathrm{O}_{2}, \\
& \mathrm{Fe}^{0}+\mathrm{H}_{2} \mathrm{O}_{2} \rightarrow \mathrm{Fe}^{2+}+2 \mathrm{OH}^{-}, \\
& \mathrm{Fe}^{0}+2 \mathrm{H}_{2} \mathrm{O} \leftrightarrow \mathrm{Fe}^{2+}+\mathrm{H}_{2}+2 \mathrm{OH}^{-}, \\
& \mathrm{Fe}^{0}+\mathrm{O}_{2}+2 \mathrm{H}_{2} \mathrm{O} \leftrightarrow \mathrm{Fe}^{2+}+4 \mathrm{OH}^{-} .
\end{aligned}
$$

It can be seen from these reaction equations that the transformation of $\mathrm{Fe}^{0}$ into $\mathrm{Fe}^{2+}$ ions is largely due to corrosion processes.

It has been found that the treatment of an aqueous phenol solution $\left(2.5 \mathrm{mmol} / \mathrm{dm}^{3}\right)$ with the Fenton reagent (at the mass ratio $\mathrm{Fe}^{0}: \mathrm{H}_{2} \mathrm{O}_{2}=1: 4$ ) for one hour, the phenol degradation of $82.5 \%$ is achieved [5].

The advantage of using the Fenton process is a full mineralization of organic compounds: there is virtually no secondary contamination, unlike traditional methods. In addition, iron (II, III) hydroxides formed in this process are easily removed by filtration.

Combinations of cavitation treatment with chemical treatment

Combination of cavitation with the treatment by

\section{hydrogen peroxide}

Under the action of cavitation treatment, hydrogen peroxide decomposes to form hydroxyl radicals, which cause the emergence of other radicals, such as peroxide $[13,47,54]$ :

$$
\begin{aligned}
& \mathrm{H}_{2} \mathrm{O}_{2} \rightarrow 2^{\bullet} \mathrm{OH} \\
& \mathrm{H}_{2} \mathrm{O}_{2}+{ }^{\bullet} \mathrm{OH} \rightarrow \mathrm{HO}_{2}^{\bullet}+\mathrm{H}_{2} \mathrm{O} \\
& 2 \mathrm{HO}_{2}^{\bullet} \rightarrow \mathrm{H}_{2} \mathrm{O}_{2}+\mathrm{O}_{2} \\
& \cdot \mathrm{OH}+\mathrm{O}_{2} \rightarrow \mathrm{HO}_{2}^{\bullet}+\mathrm{O}^{\bullet}
\end{aligned}
$$

The use of a combination of shock cavitation treatment and chemical treatment with hydrogen peroxide for the degradation of phenol at its concentration of $50 \mathrm{mg} / \mathrm{dm}^{3}$ at a neutral $\mathrm{pH}$ value caused the reduction of total organic carbon by $56.2 \%$. Shock cavitation is multifrequency (widerange excitation from 1 to $100 \mathrm{kHz}$ ), which contributes to the mineralization of phenol [55] by the following overall reaction:

$$
\mathrm{C}_{6} \mathrm{H}_{5} \mathrm{OH}+14 \mathrm{H}_{2} \mathrm{O}_{2} \rightarrow 6 \mathrm{CO}_{2}+17 \mathrm{H}_{2} \mathrm{O} \text {. }
$$

It was found that the combination of ultrasonic cavitation (at ultrasound frequency of $35 \mathrm{kHz}$ and generator power of $40 \mathrm{~W}$ ) and chemical treatment with hydrogen peroxide (solution concentration of $20 \mathrm{mmol} / \mathrm{dm}^{3}$ ) for $60 \mathrm{~min}$ contributed to a significant increase in the degree of degradation of phenol (the concentration of phenol in the original solution was $0.044 \mathrm{mmol} / \mathrm{dm}^{3}$ ) from 12 to $48 \%$ [54].

Yiyu et al. [15] achieved a phenolic mineralization rate of $99.85 \%$ when using a combination of hydrodynamic cavitation (cavitator inlet pressure of $0.5 \mathrm{MPa}$ ) and an oxidizing reagent (peroxide hydrogen). The process was carried out at a concentration of phenol in the original solution of $100 \mathrm{mg} / \mathrm{dm}^{3}$, pH of 3.0 and hydrogen peroxide concentration of $300 \mathrm{mg} / \mathrm{dm}^{3}$.

To intensify the process of cavitation decomposition of hydrogen peroxide and accordingly increase the degree of degradation of phenol, catalysts can be used that are placed in a series: $\mathrm{Fe}>\mathrm{CuO}>\mathrm{TiO}_{2}$ according to their efficiency [37].

Combination of cavitation treatment with ozonation

The collapse of the cavitation bubbles causes the achievement of the value $\mathrm{pH}<7.0$ to dissociate ozone in the gas phase with the formation of atomic oxygen [47]. It interacts with water molecules to form hydroxyl radicals as follows: 


$$
\begin{aligned}
& \mathrm{O}_{3} \stackrel{\mathrm{T}, \mathrm{P}}{\longrightarrow} \cdot \mathrm{O}+\mathrm{O}_{2}, \\
& \cdot \mathrm{O}+\mathrm{H}_{2} \rightarrow 2^{\bullet} \mathrm{OH} .
\end{aligned}
$$

In the bulk of an aqueous phase, ozone can be decomposed by hydroxyl ions with the formation of hydroxyl and peroxide radicals $[5,13,14,47,56,57]$ :

$$
\begin{aligned}
& \mathrm{H}_{2} \mathrm{O} \rightarrow \mathrm{H}^{\bullet}+{ }^{\bullet} \mathrm{OH}, \\
& \mathrm{H}_{2} \mathrm{O} \rightarrow \mathrm{H}^{+}+\mathrm{OH}^{-}, \\
& \mathrm{O}_{3}+\mathrm{OH}^{-} \rightarrow \mathrm{HO}_{2}^{-}+\mathrm{O}_{2}, \\
& \mathrm{HO}_{2}^{-}+\mathrm{H}^{+} \rightarrow \mathrm{H}_{2} \mathrm{O}_{2}, \\
& \mathrm{O}_{3}+\mathrm{HO}_{2}^{-} \rightarrow \cdot \mathrm{OH}+\mathrm{O}_{2}+\mathrm{O}_{2}^{-}, \\
& \mathrm{O}_{2}^{-}+\mathrm{H}^{+} \rightarrow \mathrm{HO}_{2}^{\cdot}, \\
& \mathrm{O}_{3}+{ }^{\bullet} \mathrm{OH} \rightarrow \mathrm{HO}_{2}^{\bullet}+\mathrm{O}_{2}, \\
& \mathrm{O}_{3}+\mathrm{O}_{2}^{-} \rightarrow \mathrm{O}_{3}^{-}+\mathrm{O}_{2}, \\
& \mathrm{O}_{3}^{-}+\mathrm{H}_{2} \mathrm{O} \rightarrow \cdot \mathrm{OH}+\mathrm{OH}^{-}+\mathrm{O}_{2}, \\
& \mathrm{HO}_{2}^{\bullet}+\mathrm{H}^{\bullet} \rightarrow \mathrm{H}_{2} \mathrm{O}_{2}, \\
& \cdot \mathrm{OH}+\mathrm{HO}_{2}^{\bullet} \rightarrow \mathrm{H}_{2} \mathrm{O}+\mathrm{O}_{2}, \\
& 2^{\circ} \mathrm{OH} \rightarrow \mathrm{H}_{2} \mathrm{O}_{2}, \\
& \mathrm{O}_{3}+\mathrm{H}_{2} \mathrm{O}_{2} \rightarrow \mathrm{O}_{2}+{ }^{\bullet} \mathrm{OH}+\mathrm{HO}_{2}^{\bullet}, \\
& \mathrm{O}_{3}+\mathrm{HO}_{2}^{\bullet} \rightarrow^{\bullet} \mathrm{OH}+2 \mathrm{O}_{2} \text {. }
\end{aligned}
$$

Kidak and Ince [14] investigated the degradation of phenol in an aqueous solution at a concentration of $2.5 \mathrm{mmol} / \mathrm{dm}^{3}$ in the course of three processes (US treatment, ozonation and combinations of ultrasound cavitation with ozonation) at different $\mathrm{pH}$ values $(2.0 ; 5.6 ; 10.0)$. It was established that the degradation rate constant at $\mathrm{pH} 2.0$ in the case of the combined process of ozonation and ultrasonic cavitation $\left(2.21 \cdot 10^{-2} \mathrm{~min}^{-1}\right)$ was higher than the rate constants of individual processes (ultrasound cavitation or ozonation), but smaller than the sum of these constants $\left(3.21 \cdot 10^{-2} \mathrm{~min}^{-1}\right)$. The combined process allows increasing the mass transfer of ozone to the solution (under the action of ultrasonic vibrations). At $\mathrm{pH}$ 10.0 , the rate constant of phenol degradation for the combined process $\left(3.26 \cdot 10^{-2} \mathrm{~min}^{-1}\right)$ was higher than the sum of the rate constants of the individual processes $\left(2.85 \cdot 10^{-2} \mathrm{~min}^{-1}\right)$, indicating the synergistic effect of the combination «ultrasound cavitation + ozonation». The synergistic effect is caused by indirect chemical reactions between ozone and hydrogen peroxide generated under the action of ultrasound with the formation of highly reactive radicals $\mathrm{HO}_{3}^{\circ}$ :

$$
\begin{aligned}
& \mathrm{H}_{2} \mathrm{O}_{2} \rightarrow \mathrm{HO}_{2}^{\bullet}+\mathrm{H}^{+}, \\
& \mathrm{O}_{3}+\mathrm{HO}_{2}^{\bullet} \rightarrow \mathrm{HO}_{3}^{\bullet}+\mathrm{O}_{2} .
\end{aligned}
$$

An additive effect was observed at $\mathrm{pH}$ 5.6: the sum of the phenol degradation rate constants of the individual processes (US cavitation and ozonation) was almost equal to the rate constant of the combined process $\left(2.90 \cdot 10^{-2} \mathrm{~min}^{-1}\right)[14]$.

A synergistic effect was also detected during the use of combinations of ultrasonic cavitation (at ultrasound frequency of $300 \mathrm{kHz}$ ) and ozonation in the presence of $\mathrm{Fe}^{0}$ and $\mathrm{Cu}^{0}$. Thus, the reduction of total organic carbon content was $5.6 \%, 12.2 \%$, and $12.0 \%$ for the process of ultrasonic cavitation using ozonation (at the consumption of $\mathrm{O}_{3}$ of $0.09 \mathrm{~g} / \mathrm{h}$ ), for the combination of ultrasonic cavitation with ozonation and introduction of $\mathrm{Fe}^{0}$, and for the combination of ultrasonic cavitation with ozonation and introduction of $\mathrm{Cu}^{0}$, respectively [5]. The initial concentration of phenol in aqueous solution was $2.5 \mathrm{mmol} / \mathrm{dm}^{3}$. The concentrations of $\mathrm{FeO}$ and $\mathrm{CuO}$ were 0.6 and $5.0 \mathrm{~g} / \mathrm{dm}^{3}$, respectively. The processing time was $60 \mathrm{~min}$ and the temperature was $293 \pm 5 \mathrm{~K}$. The $\mathrm{pH}$ of a reaction medium was 9 . The studies were carried out with three different volumes of the reaction mixture: 80,100 and $300 \mathrm{~cm}^{3}$.

Mahamuni and Pandit [16] found that the combination of ultrasonic treatment (at frequency of $22 \mathrm{kHz}$ ) and ozonation (at ozone consumption of $5 \mathrm{~cm}^{3} / \mathrm{s}$ ) increased the degradation rate of phenol (phenol concentration in the original aqueous solution was $120 \mathrm{mg} / \mathrm{dm}^{3}$ ) by $1.71 \%$ (from $93.54 \%$ to $95.25 \%$ for ozonation and combined process, respectively).

The combination of cavitation, which was caused by vacuum (pressure of $0.07 \mathrm{MPa}$ and treatment duration of $30 \mathrm{~min}$ ) and ozone (ozone consumption of $3.2 \mathrm{mg} / \mathrm{min}$ ), for the degradation of phenol allowed significantly increasing the degradation rate constant from $0.018 \mathrm{~min}^{-1}$ to $0.028 \mathrm{~min}^{-1}$ (for ozonation and combined process, respectively) [58].

The use of combinations (acoustic cavitation+ + peroxon and hydrodynamic cavitation + peroxone) resulted in a $100 \%$ phenol degradation rate [45].

The use of ozone for the degradation of organic 
compounds is limited by the occurrence of local mass transfer resistance, the influence of $\mathrm{pH}$ on possible reaction pathways with ozone, and its high cost [47].

Combination of cavitation with Fenton process

The joint action of ultrasound cavitation (ultrasound frequency of $20 \mathrm{kHz}$ and treatment duration of $60 \mathrm{~min}$ ), modified Fenton reagent $\left(0.6 \mathrm{~g} / \mathrm{dm}^{3} \mathrm{Fe}^{0}\right.$ and $2.38 \mathrm{~g} / \mathrm{dm}^{3} \mathrm{H}_{2} \mathrm{O}_{2}$ ) and air (flow rate of $1.5 \mathrm{dm}^{3} / \mathrm{min}$ ) for the degradation of phenol in an aqueous solution (concentration of $2.5 \mathrm{mmol} / \mathrm{dm}^{3}$ ) resulted in a complete mineralization of phenol [5]. The volume of aqueous phenol solution was 80,100 and $300 \mathrm{~cm}^{3}$.

The use of hydrodynamic cavitation (cavitator inlet pressure of $10.34 \mathrm{kPa}$ and treatment time of $105 \mathrm{~min})$ and modified Fenton reagent $\left(80 \mathrm{~g} \mathrm{Fe}^{0}\right.$ and $2 \mathrm{~g} / \mathrm{dm}^{3} \mathrm{H}_{2} \mathrm{O}_{2}$ ) at environment $\mathrm{pH}$ of 2.5 for sewage treatment with phenol concentration $2.5 \mathrm{mmol} / \mathrm{dm}^{3}$ caused a decrease in the total organic carbon by $50-60 \%$ [59]. The volume of the treated aqueous solution containing phenol was $4 \mathrm{dm}^{3}$.

$\mathrm{Fe}^{2+}+\mathrm{S}_{2} \mathrm{O}_{8}{ }^{2-}$ systems are often regarded as Fenton-like ones because of the similarity of the mechanisms of oxidation of organic matter to the $\mathrm{Fe}^{2+}+\mathrm{H}_{2} \mathrm{O}_{2}$ system. $\mathrm{Fe}^{2+}$ ions are a catalyst for the decomposition of persulfate ions that form sulfate anion radicals which serve as powerful oxidizers [60]:

$$
\begin{aligned}
& \mathrm{S}_{2} \mathrm{O}_{8}^{2-}+\mathrm{Fe}^{2+} \rightarrow \mathrm{SO}_{4}^{\cdot-}+\mathrm{SO}_{4}^{2-}+\mathrm{Fe}^{3+} \\
& \mathrm{SO}_{4}^{\cdot-}+\mathrm{Fe}^{2+} \rightarrow \mathrm{SO}_{4}^{2-}+\mathrm{Fe}^{3+} \\
& \mathrm{S}_{2} \mathrm{O}_{8}^{2-}+\mathrm{Fe}^{3+} \rightarrow 2 \mathrm{SO}_{4}^{\bullet-}+\mathrm{Fe}^{2+}
\end{aligned}
$$

Oxidation of organic matter occurs via a chain radical mechanism. The breakage of the chain contributes to the removal of iron ions from the reaction medium due to the formation of reaction products (aqua complexes and complexes with carbonyl ligands).

Ultrasound cavitation provides an additional pathway for the activation of persulfate ions and facilitates the breakdown of iron-containing complexes:

$$
\begin{aligned}
& \mathrm{S}_{2} \mathrm{O}_{8}^{2-} \rightarrow 2 \mathrm{SO}_{4}^{\bullet-}, \\
& \mathrm{FeOOH}^{2+} \rightarrow \mathrm{Fe}^{2+}+\mathrm{HO}_{2}^{\bullet} .
\end{aligned}
$$

\section{Photochemical methods \\ Photolysis}

The essence of photolysis is to irradiate an aqueous solution containing the pollutant by ultraviolet (UV) rays. Typically, UV lamps with a wavelength of $254 \mathrm{~nm}$ are used [61]. The major disadvantage of photolysis is the incomplete decomposition of organic compounds, which leads to the formation of intermediates, often more toxic than the starting materials [62].

At lower $\mathrm{pH}$ values, the efficiency of photolytic degradation of phenol is found to be higher. Thus, the degree of photolytic degradation of phenol after the treatment of an aqueous solution of phenol (100 $\mathrm{mg} / \mathrm{dm}^{3}$ ) by UV radiation (2 hours) was $94.0 \%$, $91.5 \%, 71.0 \%$, and $62.0 \%$ at $\mathrm{pH} 3.0, \mathrm{pH} 5.0, \mathrm{pH}$ 9.0, and $\mathrm{pH} 11.0$, respectively [63]. The power of UV radiation was 9 Watts. The volumes of aqueous phenol solution treated by UV rays were 300,600 and $800 \mathrm{~cm}^{3}$.

Combinations: photolysis with cavitation, photolysis with chemical treatment, and photolysis with cavitation and chemical treatment

The use of ultrasound intensifies the photolytic decomposition of organic compounds. Thus, the phenol degradation rate constant (phenol concentration in the stock solution is $2.5 \mathrm{mmol} / \mathrm{dm}^{3}, \mathrm{pH}$ 2.0) for the combined photolysis with ultrasound cavitation almost doubled the rate constant for the individual ultrasound application (ultrasound frequency of $300 \mathrm{kHz}): 1.8 \cdot 10^{-2} \mathrm{~min}^{-1}$ and $1.0 \cdot 10^{-2} \mathrm{~min}^{-1}$, respectively [14].

UV radiation promotes the decomposition of hydrogen peroxide and ozone to form hydroxyl radicals [64]:

$$
\begin{aligned}
& \mathrm{H}_{2} \mathrm{O}_{2} \stackrel{\mathrm{h} v}{\longrightarrow} 2^{\bullet} \mathrm{OH}, \\
& \mathrm{O}_{3}+\mathrm{H}_{2} \mathrm{O} \stackrel{\mathrm{h} v}{\longrightarrow} 2^{\bullet} \mathrm{OH}+\mathrm{O}_{2},
\end{aligned}
$$

Kidak and Ince [14] found that the rate of the degradation of phenol (phenol concentration in aqueous solution was $2.5 \mathrm{mmol} / \mathrm{dm}^{3}$ ) at $\mathrm{pH} 10.0$ for the combined process involving photolysis and ozonation was much higher than for the photolysis alone: $8.69 \cdot 10^{-2} \mathrm{~min}^{-1}$ and $0.21 \cdot 10^{-2} \mathrm{~min}^{-1}$, respectively.

A synergistic effect was found for the combination of ultrasound cavitation and the photoFenton process during phenol degradation. Thus, the synergistic index for the combined process «photolysis+ultrasound cavitation+Fenton's reagent» was 1.99 [65]. The use of this combination for the degradation of phenol in an aqueous solution $\left(200 \mathrm{mg} / \mathrm{dm}^{3}\right.$ at $\mathrm{pH} 3.0$ and a temperature of $\left.298 \mathrm{~K}\right)$ provided the degree of phenol degradation of $93 \%$ and a decrease in the amount of chemical oxygen consumption by $84.6 \%$ [47]. The study conditions 
were as follows: treatment duration of $600 \mathrm{~min}$, ultrasonic generator power of $120 \mathrm{~W}$, ultrasonic frequency of $34 \mathrm{kHz}$; UV lamp power of $250 \mathrm{~W}$; UV radiation wavelength of $420 \mathrm{~nm}$; $\mathrm{Fe}^{2+}$ ions concentration of $20 \mathrm{mg} / \mathrm{dm}^{3}$, and hydrogen peroxide concentration of $700 \mathrm{mg} / \mathrm{dm}^{3}$.

\section{Photocatalysis}

During photocatalysis, the photocatalyst (chiefly, $\mathrm{TiO}_{2}, \mathrm{ZnO}, \mathrm{CuO}$, and some other oxides of transition metal) $[7,48,62,64]$ is subjected to UV radiation that causes the electrons to pass from the valence band to the conduction band in which the electron-hole pair arises. The hole $\left(\mathrm{h}^{+}\right)$formed in the valence band of $\mathrm{TiO}_{2}$ has an oxidation potential of $3.2 \mathrm{eV}$ at $\mathrm{pH}$ 7.0. This can cause the water molecules to oxidize to form hydroxyl radicals. Typical reactions for photocatalysis are described by the following equations [48]:

$$
\begin{aligned}
& \mathrm{TiO}_{2} \stackrel{\mathrm{h} v}{\longrightarrow} \mathrm{e}^{-}+\mathrm{h}^{+}, \\
& \mathrm{h}^{+}+\mathrm{H}_{2} \mathrm{O} \rightarrow \cdot \mathrm{OH}+\mathrm{H}^{+}, \\
& \mathrm{h}^{+}+\mathrm{OH}^{-} \rightarrow \cdot \mathrm{OH} .
\end{aligned}
$$

Oxygen dissolved in water contributes to the further generation of radicals (superoxide and peroxide):

$$
\begin{aligned}
& 2 \mathrm{~h}^{+}+2 \mathrm{H}_{2} \mathrm{O} \rightarrow \mathrm{H}_{2} \mathrm{O}_{2}+2 \mathrm{H}^{+}, \\
& \mathrm{e}^{-}+\mathrm{O}_{2} \rightarrow \mathrm{O}_{2}^{\bullet-}, \\
& \mathrm{O}_{2}+\mathrm{e}^{-}+\mathrm{H}^{+} \rightarrow \mathrm{HO}_{2}^{\bullet-} \\
& \mathrm{O}_{2}^{\bullet-}+\mathrm{H}_{2} \mathrm{O}_{2} \rightarrow \cdot \mathrm{OH}+\mathrm{OH}^{-}+\mathrm{O}_{2}, \\
& \mathrm{O}_{2}^{\bullet-}+\mathrm{e}^{-}+2 \mathrm{H}^{+} \rightarrow \mathrm{H}_{2} \mathrm{O}_{2}, \\
& \mathrm{O}_{2}+2 \mathrm{e}^{-}+2 \mathrm{H}^{+} \rightarrow \mathrm{H}_{2} \mathrm{O}_{2} .
\end{aligned}
$$

In order to increase photon absorption capacity, photocatalysts are doped with transition metal ions (e.g. $\mathrm{Fe}^{3+}, \mathrm{Co}^{2+}, \mathrm{Ni}^{2+}$, etc.) [48].

Commonly, photocatalytic systems operate at ambient temperature, however the temperature can rise as a result of the release of energy during degradation which is explained by the recombination of electron-hole pairs. If the temperature exceeds $353 \mathrm{~K}$, intermediate cooling is recommended. The adsorption rate of the pollutant sharply decreases at $353 \mathrm{~K}$ which leads to a decrease in the activity of the photocatalyst and consequently to the reduction of degradation efficiency [30]. Therefore, the range of optimal temperatures for the efficient operation of photocatalytic systems is about $293-353 \mathrm{~K}$, since such temperatures show only a slight influence on the rate of degradation.

The presence of anions in aqueous solutions of organic pollutants reduces the efficiency of their photocatalytic degradation. With respect to the antagonistic effect on the efficiency of photocatalysis, anions were placed in the following order [30]: $\mathrm{HCO}_{3}^{-}>\mathrm{Cl}^{-}>\mathrm{CO}_{3}^{2-}>\mathrm{SO}_{4}^{2-}$. Thus, the addition of an aqueous solution of sodium sulfate $\left(0.25 \mathrm{~mol} / \mathrm{dm}^{3}\right)$ to an aqueous solution of phenol $\left(1 \mathrm{mmol} / \mathrm{dm}^{3}\right)$ reduces the degree of photocatalytic degradation of phenol for $140 \mathrm{~min}$ by $6 \%$ (from 58 to $52 \%$, the concentration of $\mathrm{TiO}_{2}$ photocatalyst in solution was $\left.0.25 \mathrm{~g} / \mathrm{dm}^{3}\right)$, whereas the addition of aqueous sodium chloride solution (concentration $0.5 \mathrm{~mol} / \mathrm{dm}^{3}$ ) reduces the degree of phenol photocatalytic degradation by $30 \%$ (from $58 \%$ to 28\%) [66].

High efficiency and enhanced rate of degradation of pollutants are the main advantages of photocatalysis technique. Disadvantages include the difficulty of separating the photocatalyst from the purified liquid and high operating costs of handling large volumes of runoffs [7].

Combination of photocatalysis with cavitation

Acoustic cavitation promotes purification and enlargement of the photocatalyst surface, intensifies the processes of mass transfer of reagents and products to the photocatalyst surface, and increases the degree of degradation of the pollutants due to the generation of additional hydroxyl radicals [30]. During ultrasonic treatment, the rate of photocatalytic degradation of phenol is directly proportional to the amount of photocatalyst $\left(\mathrm{TiO}_{2}\right)$ and the content of dissolved oxygen in water [57].

For the treatment of large volumes of wastewater, it is important to develop sonophotocatalytic reactors that operate in continuous or at least recirculating modes. To ensure uniform cavitation, ultrasonic bath reactors or parallel plate reactors with several transducers are recommended. Multifrequency sonophotocatalytic reactors are the most efficient, they provide a very high intensity and uniformity of cavitation. An increase in the rate of sonophotocatalytic degradation of phenol can be achieved by introducing hydrogen peroxide or Fenton reagent into the reaction system [13].

Combination of photocatalysis (anatase $\mathrm{TiO}_{2}$ with the concentration in solution of $0.25 \mathrm{~g} / \mathrm{dm}^{3}$, UV wavelength of $320 \mathrm{~nm}$, UV lamp power of $450 \mathrm{~W}$ and irradiation duration of $140 \mathrm{~min}$ ) with 
acoustic cavitation (US frequency of $20 \mathrm{kHz}$ and treatment duration of $140 \mathrm{~min}$ ) led to an increase in the degree of degradation of phenol (the initial concentration of phenol in aqueous solution was 1 $\mathrm{mmol} / \mathrm{dm}^{3}$ and the volume of solution was $100 \mathrm{~cm}^{3}$ ) by $38 \%$ : from $58 \%$ to $96 \%$ [66].

Ghodke et al. [6] established that the use of a combination of photocatalysis (a Xe-lamp with a power of $300 \mathrm{~W}$ as a UV source, the concentration of nanocomposite photocatalyst $\mathrm{TiO}_{2}$-nanoclay was $0.75 \mathrm{~g} / 100 \mathrm{~mL}$ of an aqueous solution of phenol with a contaminant concentration of $500 \mathrm{mg} / \mathrm{dm}^{3}$, and the particle size of the photocatalyst of 30$40 \mathrm{~nm}$ ) with acoustic cavitation (ultrasound frequency of $22.5 \mathrm{kHz}$ and nominal power of the ultrasound generator of $240 \mathrm{~W}$ ) allowed achieving the degradation rate of phenol equal to 59\% (for 1 hour at $\mathrm{pH} 7.0$ and the reaction system temperature of $303 \mathrm{~K})$.

\section{Electrochemical methods}

In electrochemical processes, hydroxyl radicals are generated by the excitation and decomposition of water molecules in the gas phase near the anode [11]:

$$
\begin{aligned}
& \mathrm{H}_{2} \mathrm{O}-\mathrm{e}^{-} \rightarrow \mathrm{H}_{2} \mathrm{O}_{\mathrm{g}}^{+}, \\
& \mathrm{H}_{2} \mathrm{O}_{\mathrm{g}}^{+}+\mathrm{H}_{2} \mathrm{O} \rightarrow{ }^{\cdot} \mathrm{OH}+\mathrm{H}_{3} \mathrm{O}^{+} .
\end{aligned}
$$

The efficiency of electrochemical degradation of phenol-containing wastewater is affected by the working voltage, electrolyte composition, anode immersion depth and the presence of ions, such as $\mathrm{Fe}^{2+}$ (for the implementation of Fenton process). It was established that the degree of electrochemical degradation of phenol was $40.83 \%$ and energy consumption was $278 \mathrm{~kJ} / \mathrm{mmol}$ of phenol under following conditions: electrolyzer voltage of $700 \mathrm{~V}$, electrolysis duration of $15 \mathrm{~min}$, sodium sulfate concentration of $0.03 \mathrm{~mol} / \mathrm{dm}^{3}$ and the depth of anode immersion in electrolyte of $5 \mathrm{~mm}$. Under the same conditions, the addition of $\mathrm{Fe}^{2+}$ ions $\left(20 \mathrm{mg} / \mathrm{dm}^{3}\right)$ led to an increase in the degree of degradation of phenol to $92.57 \%$ while reducing energy consumption to $127 \mathrm{~kJ} / \mathrm{mmol}$ of phenol. The highest degree of electrochemical degradation of phenol, amounting to $99.6 \%$, was achieved in the presence of $\mathrm{Fe}^{2+}$ ions and the electrolysis duration of 90 min [11].

Combination of electrochemical oxidation with cavitation (sonoelectrochemistry)

The combination of electrochemical oxidation and acoustic cavitation considerably intensifies wastewater treatment processes due to the combination of mechanical action of US (activation of the electrode surface and intensification of mass transfer in a solid-liquid system) and chemical effects (possible changes in mechanism). «Very mild» conditions are considered to be a significant advantage of sonoelectrochemical processes for the oxidation of organic matter [13].

Trabelsi et al. [67] determined that the use of high-frequency ultrasound $(540 \mathrm{kHz})$ increased the rate of diffusion mass transfer by 70 times, while low-frequency ultrasound $(20 \mathrm{kHz})$ increased it by 120 times. However, the efficiency of hydroxyl radical generation is higher for high-frequency ultrasonic transducers. Due to the combination of electrochemical oxidation (nickel as a cathode material; titanium coated with platinum as a anode material; current density of $68 \mathrm{~A} / \mathrm{m}^{2}$; aqueous sodium chloride solution with a concentration of $0.5 \mathrm{~g} / \mathrm{dm}^{3}$ ) with acoustic cavitation (US frequency of $20 \mathrm{kHz}$ ) within $10 \mathrm{~min}$, the phenol degradation rate achieved the value of $75 \%$ (the initial concentration of phenol in its aqueous solution with a volume $200 \mathrm{~cm}^{3}$ being $100 \mathrm{mg} / \mathrm{dm}^{3}$ ). At the same time, the formation of a toxic product, 1,4-benzoquinone, was detected. An increase in the frequency of ultrasound to $540 \mathrm{kHz}$ under similar conditions of purification contributed to an increase in the degree of degradation of phenol up to $95 \%$, and toxic aromatic products were not formed.

Combination of enzymatic treatment with cavitation

As compared with traditional biological treatment methods of wastewater from organic compounds, the use of enzymes has some advantages, such as high selectivity, the removal of toxic pollutants, the simplification of storage operations and the use of enzymes. However, the enzymatic purification also exhibit significant disadvantages, such as a relatively small period of catalytic activity of enzymes, high costs of the catalyst, the possibility of the formation of harmful soluble by-products and the need to dispose of solid waste. The use of a combination of enzymatic purification and cavitation allows eliminating some of these disadvantages, and the similarity of principles of operation in these processes (generation of free radicals and their interaction with the pollutant) yields synergistic effects [13].

The combination of enzymatic purification (peroxidase as enzyme; temperature of $303 \mathrm{~K}$ ) and acoustic cavitation (US frequency of $423 \mathrm{kHz}$; treatment duration of $45 \mathrm{~min}$ ) caused an increase in the rate of phenol degradation by $56 \%$ : it was $3.4 \cdot 10^{-2} \mathrm{~min}^{-1}$ and $5.3 \cdot 10^{-2} \mathrm{~min}^{-1}$ for the individual cavitation purification process and for the combined 
process, respectively [68].

Economic assessment of the cost of wastewater treatment from phenol

Mahamuni and Adewuyi [64] performed a comparative analysis of the cost of sewage treatment of phenol by different methods. Their results showed that the most cost-effective method involving the use of ultrasound cavitation is a combination of ultrasound cavitation with photolysis and ozonation.

\section{Conclusions}

Highly reactive hydroxyl radicals contribute to the treatment of phenol-containing wastewater. Depending on the method of generating hydroxyl radicals, all purification methods based on advanced oxidation processes are classified as follows: chemical (acoustic and hydrodynamic cavitation, the use of oxidants, Fenton process and Fenton-like processes); photochemical (photolysis and photocatalysis); electrochemical and combined ones. The use of a particular method for the degradation of phenol will be determined by its content in the effluents, the volume of effluents, the required degree of degradation, the duration of purification process and economic indicators.

\section{Acknowledgments}

The work was supported by the Ministry of Education and Science of Ukraine within the framework of the joint Ukrainian-Indian research project «Hydrodynamic cavitation based intensified and low cost technology for industrial wastewater treatment containing toxic organic compounds and solid particles».

\section{REFERENCES}

1. Kidak R., Ince N.H. Effects of operating parameters on sonochemical decomposition of phenol // J. Hazard. Mater. 2006. - Vol.137. - No. 3. - P.1453-1457.

2. Effect of coal ash on sonochemical degradation of phenol in water / Nakui H., Okitsu K., Maeda Y., Nishimura R. // Ultrason. Sonochem. - 2007. - Vol.14. - No. 2. - P.191-196.

3. Kidak R., Ince N.H. Ultrasonic destruction of phenol and substituted phenols: a review of current research // Ultrason. Sonochem. - 2006. - Vol.13. - No. 3. - P.195-199.

4. Ultrasound-assisted adsorption of phenol from aqueous solution by using spent black tea leaves / Ali A., Bilal M., Khan R., Farooq R., Siddique M. // Environ. Sci. Pollut. Res. - 2018. Vol.25. - No. 23. - P.22920-22930.

5. Phenol degradation using 20, 300 and $520 \mathrm{kHz}$ ultrasonic reactors with hydrogen peroxide, ozone and zero valent metals / Chand R., Ince N.H., Gogate P.R., Bremner D.H. // Sep. Purif. Technol. - 2009. - Vol.67. - No. 1. - P.103-109.

6. $\mathrm{TiO}_{2} /$ nanoclay nanocomposite for phenol degradation in sonophotocatalytic reactor / Ghodke S., Sonawane S., Gaikawad R., Mohite K.C. // Can. J. Chem. Eng. - 2012. Vol.90. - No. 5. - P.1153-1159.

7. Singh V.R., Bagal M.V., Mota R.P. Phenolic wastewater treatment: a review // Int. J. Adv. Eng. Res. Dev. - 2018. Vol.5. - No. 5. - Article No. 15994.

8. Degradation of phenol by combination of ozonation and cavitation / Karamah E.F., Tjahjadi L., Bismo S., Purwanto W.W. // Proceed. 12th Int. Conf. QiR. - Indonesia: Bali, 2011. P.119-126.

9. Bapat P.S., Gogate P.R., Pandit A.B. Theoretical analysis of sonochemical degradation of phenol and its chloro-derivatives // Ultrason. Sonochem. - 2008. - Vol.15. - No. 4. - P.564-570.

10. Bi Y.-G., Zheng Y.-H., Zhou S.-Q. Study on the process of degradation of phenolic compounds water by slot ultrasonic // E3S Web 4th Int. Conf. Adv. Energy Environ. Res. (ICAEER). - 2019. - Vol.118. - Article No. 03050.

11. Phenol degradation in wastewater with a contact glow discharge electrolysis reactor using a sodium sulfate / Saksono N., Seratri R.T., Muthia R., Bismo S. // Int. J. Technol. - 2015. Vol.6. - No. 7. - P.1153-1163.

12. Developing of effective treatment technology of the phenolic wastewater / Klymenko I., Yelatontsev D., Ivanchenko A., Dupenko O., Voloshyn M. // East. Eur. J. Enterprise Technol. 2016. - Vol.3. - No. 10(81). - P.29-34.

13. Gogate P.R. Treatment of wastewater streams containing phenolic compounds using hybrid techniques based on cavitation: a review of the current status and the way forward // Ultrason. Sonochem. - 2008. - Vol.15. - No. 1. - P.1-15.

14. Kidak R., Ince N.H. Catalysis of advanced oxidation reactions by ultrasound: a case study with phenol // J. Hazard. Mater. - 2007. - Vol.146. - No. 3. - P.630-635.

15. Phenol oxidation by combined cavitation water jet and hydrogen peroxide / Lu Y., Liu Y., Xia B., Zuo W. // Chin. J. Chem. Eng. - 2012. - Vol.20. - No. 4. - P.760-767.

16. Mahamuni N.N., Pandit A.B. Effect of additives on ultrasonic degradation of phenol // Ultrason. Sonochem. - 2006. - Vol.13. - No. 2. - P.165-174.

17. Sivasankar T., Moholkar V.S. Mechanistic features of the sonochemical degradation of organic pollutants // AIChE J. - 2008. - Vol.54. - P.2206-2219.

18. Sivasankar T., Moholkar V.S. Physical insights into the sonochemical degradation of recalcitrant organic pollutants with cavitation bubble dynamics // Ultrason. Sonochem. - 2009. Vol.16. - No. 6. - P.769-781.

19. Sivasankar T., Moholkar V.S. Mechanistic approach to intensification of sonochemical degradation of phenol // Chem. Eng. J. - 2009. - Vol.149. - No. 1-3. - P.57-69.

20. Modeling of ultrasonic degradation of non-volatile organic compounds by Langmuir-type kinetics / Chiha M., Merouani S., Hamdaoui O., Baup S., Gondrexon N., Petrier C. // Ultrason. Sonochem. - 2010. - Vol.17. - No. 5. - P.773-782.

21. Sonochemical oxidation of phenol and three of its intermediate products in aqueous media: catechol, hydroquinone, 
and benzoquinone. Kinetic and mechanistic aspects / Serpone N., Terzian R., Colarusso P., Minero C., Pelizzetti E., Hidaka H. // Res. Chem. Intermed. - 1993. - Vol.18. - No. 2. - P.183-202.

22. Petrier C., Francony A. Ultrasonic waste-water treatment: incidence of ultrasonic frequency on the rate of phenol and carbon tetrachloride degradation // Ultrason. Sonochem. 1997. - Vol.4. - No. 4. - P.295-300.

23. Lesko T., Colussi A.J., Hoffmann M.R. Sonochemical decomposition of phenol: evidence for a synergistic effect of ozone and ultrasound for the elimination of total organic carbon from water // Environ. Sci. Technol. - 2006. - Vol.40. - No. 21. P.6818-6823.

24. Okouchi S., Nojima O., Arai T. Cavitation-induced degradation of phenol by ultrasound // Water Sci. Technol. 1992. - Vol.26. - No. 11. - P.2053-2056.

25. Petrier C., Francony A. Incidence of wave-frequency on the reaction rates during ultrasonic wastewater treatment // Water Sci. Technol. - 1997. - Vol.35. - No. 4. - P.175-180.

26. Termokhimichnyi analiz energetyky protsessu sonolizu vody u kavitatsiinykh polyakh / Znak Z.O., Sukhatskiy Yu.V., Mnykh R.V., Tkach Z.S. // Voprosy Khimii i Khimicheskoi Tekhnologii. - 2018. - No. 3. - P.64-69.

27. Mechanism of the sonochemical production of hydrogen / Merouani S., Hamdaoui O., Rezgui Y., Guemini M. // Int. J. Hydrogen Energy. - 2015. - Vol.40. - P.4056-4064.

28. Rozklad benzolu v kavitatsiinykh polyakh / Znak Z.O., Sukhatskiy Yu.V., Zin O.I., Khomyak S.V., Mnykh R.V., Lysenko A.V. // Voprosy Khimii i Khimicheskoi Tekhnologii. 2018. - No. 1. - P.72-77.

29. Intensyfikatsiya kavitatsiinogo rozkladu benzenu / Znak Z.O., Sukhatskiy Yu.V., Zin O.I., Vyrsta K.R. // Voprosy Khimii i Khimicheskoi Tekhnologii. - 2019. - No. 4. - P.55-61.

30. Gogate P.R., Pandit A.B. Sonophotocatalytic reactors for wastewater treatment: a critical review // AIChE J. - 2004. Vol.50. - No. 5. - P.1051-1079.

31. Synergistic sonoelectrochemical removal of substituted phenols: implications of ultrasonic parameters and physicochemical properties / Kim K., Cho E., Thokchom B., Cui M., Jang M., Khim J. // Ultrason. Sonochem. - 2015. Vol.24. - P.172-177.

32. Timofeeva S.S., Batoeva A.A. Wastewater of enterprises for the extraction and processing of ore gold and combined technologies for their disposal // Vestnik IrGTU. - 2013. No. 11 (82). - P.132-142.

33. Deng J. Study of porous plate hydrodynamic cavitation device for p-nitrophenol // Adv. Mater. Res. - 2014. - Vol.1015. - P.385-388.

34. Marwan M. Kinetics of phenol degradation in aqueous solution oxidized under low frequency ultrasonic irradiation // Jurnal Rekayasa Kimia \& Lingkungan. - 2014. - Vol.10. No. 1. - P.34-39.

35. New design approaches for ultrasonic reactors: degradation of naphthalene and phenol in water / Her N.-G., Park J.-S., Oh J., Yoon Y. // Water, Air, Soil Pollut. - 2011. -
Vol.220. - No. 1-4. - P.173-180.

36. Effect of cavitation hydrodynamic parameters on bisphenol A removal / Lu G., Zhao L., Zhu M., Deng C., Liu H., Ma J., Li Y. // Environ. Eng. Sci. - 2019. - Vol.36. No. 8. - P.873-882.

37. Effects of operating parameters and additives on degradation of phenol in water by the combination of $\mathrm{H}_{2} \mathrm{O}_{2}$ and hydrodynamic cavitation / Wu C.D., Zhang Z.L., Wu Y., Wang L., Chen L.J. // Desalin. Water Treat. - 2015. - Vol.53. No. 2. - P.462-468.

38. Znak Z., Sukhatskiy Yu. The Brandon method in modelling the cavitation processing of aqueous media // East. Eur. J. Enterprise Technol. - 2016. - Vol.3. - No. 8(81). P.37-42.

39. Energy characteristics of treatment of corrosive aqueous media in hydrodynamic cavitators / Yavors'kyi V.T., Znak Z.O., Sukhats'kyi Yu.V., Mnykh R.V. // Mater. Sci. - 2017. - Vol.52. - No. 4. - P.595-600.

40. Investigations of cavitation processes in different types of emitters using sonochemical analysis / Yavorskiy V., Sukhatskiy Y., Znak Z., Mnykh R. // Chem. Chem. Technol. 2016. - Vol.10. - No. 4. - P.507-513.

41. Gogate P.R., Pandit A.B. A review of imperative technologies for wastewater treatment I: oxidation technologies at ambient conditions // Adv. Environ. Res. - 2004. - Vol.8. No. 3-4. - P.501-551.

42. Sivasankar T., Moholkar V.S. Physical insight into the sonochemical degradation of 2,4-dichlorophenol // Environ. Technol. - 2010. - Vol.31. - No. 14. - P.1483-1494.

43. Drijvers D., van Langenhove H., Beckers $M$. Decomposition of phenol and trichloroethylene by the ultrasound/ $\mathrm{H}_{2} \mathrm{O}_{2} / \mathrm{CuO}$ process // Water Res. - 1999. - Vol.33. - No. 5. P.1187-1194.

44. Study of degradation of phenol in waste water sample via advanced oxidation technology / Wu J., Jia R., Liu C., Wang H. // Proceed. 2015 Int. Forum Energy Environ. Sci. Mater. - 2015. - P. 584-587.

45. Gagol M., Przyjazny A., Boczkaj G. Highly effective degradation of selected groups of organic compounds by cavitation based AOPs under basic pH conditions // Ultrason. Sonochem. - 2018. - Vol.45. - P.257-266.

46. Sonolytic degradation of bisphenol S: effect of dissolved oxygen and peroxydisulfate, oxidation products and acute toxicity / Lu X., Zhao J., Wang Q., Wang D., Xu H., Ma J., Qiu W., Hu T. // Water Res. - 2019. - Vol.165. - Article No. 114969.

47. Gagol M., Przyjazny A., Boczkaj G. Wastewater treatment by means of advanced oxidation processes based on cavitation a review // Chem. Eng. J. - 2018. - Vol.338. - P.599-627.

48. Chakma S., Moholkar V.S. Intensification of wastewater treatment using sono-hybrid processes: an overview of mechanistic synergism // Ind. Chem. Eng. - 2015. - Vol.57. - No. 3-4. P.359-381.

49. Enhanced degradation of nonylphenol at neutral $\mathrm{pH}$ by ultrasonic assisted-heterogeneous Fenton using nano zero valent 
metals / ElShafei G.M.S., Yehia F.Z., Eshaq Gh., ElMetwally A.E. // Sep. Purif. Technol. - 2017. - Vol.178. - P.122-129.

50. Ultrasonic-enhanced Fenton-like degradation of bisphenol A using a bio-synthesized schwertmannite catalyst / Li X., Zhang Y., Xie Y., Zeng Y., Li P., Xie T., Wang Y. // J. Hazard. Mater. - 2018. - Vol.344. - P.689-697.

51. Mineralization of phenol by a heterogeneous ultrasound/ Fe-SBA- $15 / \mathrm{H}_{2} \mathrm{O}_{2}$ process: multivariate study by factorial design of experiments / Molina R., Martinez F., Melero J.A., Bremner D.H., Chakinala A.G. // Appl. Catal. B. - 2006. Vol.66. - No. 3-4. - P.198-207.

52. Integrated heterogeneous sono-photo Fenton processes for the degradation of phenolic aqueous solutions / Segura Y., Molina R., Martinez F., Melero J.A. // Ultrason. Sonochem. 2009. - Vol.16. - No. 3. - P.417-424.

53. Simultaneous degradation of $4 \mathrm{CP}$ and EDTA in a heterogeneous ultrasound/Fenton like system at ambient circumstance / Zhou T., Lim T.-T., Lu X., Li Y., Wong F.-S. // Sep. Purif. Technol. - 2009. - Vol.68. - No. 3. - P.367-374.

54. Lim M., Son Y., Khim J. The effects of hydrogen peroxide on the sonochemical degradation of phenol and bisphenol A // Ultrason. Sonochem. - 2014. - Vol.21. - No. 6. - P.1976-1981.

55. Shock-induced cavitation as a way of accelerating phenol oxidation in aqueous media / Dutilleul H., Partaloglu A., da Costa P., Galvez M.E. // Chem. Eng. Process. - 2017. Vol.112. - P.47-55.

56. Thanekar P., Gogate P. Application of hydrodynamic cavitation reactors for treatment of wastewater containing organic pollutants: intensification using hybrid approaches // Fluids. 2018. - Vol.3. - Article No. 98.

57. A review of combined advanced oxidation technologies for the removal of organic pollutants from water / Tijani J.O., Fatoba O.O., Madzivire G., Petrik L.F. // Water, Air, Soil Pollut. - 2014. - Vol.225. - Article No. 2102.

58. Enhanced effect of suction-cavitation on the ozonation of phenol / Wu Z., Franke M., Ondruschka B., Zhang Y., Ren Y., Braeutigam P., Wang W. // J. Hazard. Mater. - 2011. Vol.190. - No. 1-3. - P.375-380.

59. Multivariate analysis of phenol mineralisation by combined hydrodynamic cavitation and heterogeneous advanced Fenton processing / Chakinala A.G., Bremner D.H., Gogate P.R., Namkung K.-C., Burgess A.E. // Appl. Catal. B. - 2008. Vol.78. - No. 1-2. - P.11-18.

60. Aseev D.G., Sizykh M.R., Batoeva A.A. Oxidative degradation of phenols in sono-Fenton-like systems upon highfrequency ultrasound irradiation // Russ. J. Phys. Chem. A. 2017. - Vol.91. - No. 12. - P.2331-2336.

61. Khokhawala I.M., Gogate P.R. Degradation of phenol using a combination of ultrasonic and UV irradiations at pilot scale operation // Ultrason. Sonochem. - 2010. - Vol.17. No. 5. - P.833-838.

62. Sonophotocatalysis in advanced oxidation process: a short review / Joseph C.G., Puma G.L., Bono A., Krishnaiah D. // Ultrason. Sonochem. - 2009. - Vol.16. - No. 5. - P.583-589.
63. Mahvi A.H. Application of ultrasonic technology for water and wastewater treatment // Iranian J. Public Health. 2009. - Vol.38. - No. 2. - P.1-17.

64. Mahamuni N.N., Adewuyi Y.G. Advanced oxidation processes (AOPs) involving ultrasound for waste water treatment: a review with emphasis on cost estimation // Ultrason. Sonochem. - 2010. - Vol.17. - No. 6. - P.990-1003.

65. Coupling between high-frequency ultrasound and solar photo-Fenton at pilot scale for the treatment of organic contaminants: an initial approach / Papoutsakis S., MirallesCuevas S., Gondrexon N., Baup S., Malato S., Pulgarin C. // Ultrason. Sonochem. - 2015. - Vol.22. - P.527-534.

66. Chen Y.-C., Smirniotis P. Enhancement of photocatalytic degradation of phenol and chlorophenols by ultrasound // Ind. Eng. Chem. Res. - 2002. - Vol.41. - No. 24. - P.5958-5965.

67. Oxidation of phenol in wastewater by sonoelectrochemistry / Trabelsi F., Ait-Lyazidi H., Ratsimba B., Wilhelm A.M., Delmas H., Fabre P.-L., Berlan J. // Chem. Eng. Sci. - 1996. - Vol.51. - No. 10. - P.1857-1865.

68 Entezari M.H., Petrier C. A combination of ultrasound and oxidative enzyme: sono-enzyme degradation of phenols in a mixture // Ultrason. Sonochem. - 2005. - Vol.12. - No. 4. P.283-288.

Received 13.04.2020

\section{КАВІТАЦІЯ ТА ІІЇ КОМБІНАЦІЇ 3 ІНШИМИ \\ ПЕРЕДОВИМИ ПРОЦЕСАМИ ОКИСЛЕННЯ ДЛЯ ОЧИЩЕННЯ СТІЧНИХ ВОД ВІД ФЕНОЛУ: ОГЛЯД}

\section{Ю.В. Сухацький, З.О. Знак, О.І. Зінь}

В огляді систематизовано теоретичні уявлення про механізм сонохімічної деградації фенолу. Зазначено, що основний внесок у сонохімічну деградацію фенолу, як гідрофільного нелеткого компонента стічних вод, належить гідроксилюванню на межі «кавітаційна бульбашка-водний розчин забруднювача». Залежно від способу генерування гідроксильних радикалів всі методи очищення стічних вод від фенолу, засновані на передових процесах окислення, класифіковано на хімічні (акустична та гідродинамічна кавітація, використання реагентівокисників, процес Фентона та Фентон-подібні процеси), фотохімічні (фотоліз, фотокаталіз), електрохімічні та комбіновані. Розкрито сутність цих методів, описано їх основні переваги та недоліки. Показано, що ефективність комбінованих методів деградації фенолу, шо базуються на використанні кавітації (акустичної або гідродинамічної), залежсть від потужності ультразвукових випромінювачів, частоти ультразвуку, величини тиску на вході у гідродинамічний кавітатор, фізикохімічних властивостей середовищ (температури, $\mathrm{pH}$ ), початкової концентрації фенолу у водному середовищі, конструктивних особливостей генераторів кавітації, наявності розчинених у воді газів або твердих частинок, які виявляють каталітичні властивості, витрати реагентів-окисників. На основі порівняльного оцінювання витрат на очищення феноловмісних стічних вод виявлено, що найбільш економічно вигідним методом, який базується на використанні ультразвукової кавітації, є комбінація «ультразвукова кавітація+фотоліз +озонування». Встановлено, що застосування того чи іншого методу для деградації фенолу буде зумовлено його вмістом у стоках, об'ємом

Cavitation and its combinations with other advanced oxidation processes in phenol wastewater treatment: $a$ review 
стоків, необхідним ступенем деградації, тривалістю процесу очищення, шо визначається швидкістю деградації фенолу, та економічними показниками.

Ключові слова: кавітація, фенол, гідроксильні радикали, ультразвук, процес Фентона, фотоліз, фотокаталіз.

\section{CAVITATION AND ITS COMBINATIONS WITH OTHER ADVANCED OXIDATION PROCESSES IN PHENOL WASTEWATER TREATMENT: A REVIEW}

\author{
Yu.V. Sukhatskiy *, Z.O. Znak, O.I. Zin \\ Lviv Polytechnic National University, Lviv, Ukraine \\ * e-mail: yurii.v.sukhatskyi@Ipnu.ua
}

The review provides a systematic understanding of the mechanism of the sonochemical degradation of phenol. It was shown that the main contribution to the sonochemical degradation of phenol, a hydrophilic non-volatile wastewater component, is related to hydroxylation on the boundary of the "cavitation bubble-water contaminant solution». Depending on the method of generating hydroxyl radicals, all wastewater treatment methods for phenol removal based on advanced oxidation processes are classified into the following categories: chemical (acoustic and hydrodynamic cavitation, use of oxidants, Fenton process, and Fenton-like processes), photochemical (photolysis and photocatalysis), electrochemical and combined techniques. The essence of these methods is revealed and their main advantages and disadvantages are reviewed. It is shown that the efficiency of combined methods of phenol degradation that are based on the use of cavitation (acoustic or hydrodynamic) depends on the power of ultrasonic emitters, the frequency of ultrasonic vibrations, the magnitude of the pressure at the inlet of the hydrodynamic cavitator, physicochemical properties of media (temperature and $p H$ ), initial phenol concentration in aqueous medium, the design features of the cavitation generators, the presence of water-soluble gases or solid particles that exhibit catalytic properties, and the consumption of oxidizing reagents. Literature data showed that the most cost-effective method involving the use of ultrasonic cavitation is a combination «ultrasonic cavitation + photolysis +ozonation». The choice of a particular method for the degradation of phenol is determined by its content in wastewaters and their volume, the required degree of degradation, the duration of the purification process (the rate of degradation of the phenol), and economic indicators.

Keywords: cavitation; phenol; hydroxyl radicals; ultrasound; Fenton process; photolysis; photocatalysis.

\section{REFERENCES}

1. Kidak R., Ince N.H. Effects of operating parameters on sonochemical decomposition of phenol. Journal of Hazardous Materials, 2006, vol. 137, pp. 1453-1457.

2. Nakui H., Okitsu K., Maeda Y., Nishimura R. Effect of coal ash on sonochemical degradation of phenol in water. Ultrasonics Sonochemistry, 2007, vol. 14, pp. 191-196.

3. Kidak R., Ince N.H. Ultrasonic destruction of phenol and substituted phenols: a review of current research. Ultrasonics Sonochemistry, 2006, vol. 13, pp. 195-199.

4. Ali A., Bilal M., Khan R., Farooq R., Siddique M. Ultrasound-assisted adsorption of phenol from aqueous solution by using spent black tea leaves. Environmental Science and Pollution Research, 2018, vol. 25, no. 23, pp. 22920-22930.
5. Chand R., Ince N.H., Gogate P.R., Bremner D.H. Phenol degradation using 20,300 and $520 \mathrm{kHz}$ ultrasonic reactors with hydrogen peroxide, ozone and zero valent metals. Separation and Purification Technology, 2009, vol. 67, pp. 103-109.

6. Ghodke S., Sonawane S., Gaikawad R., Mohite K.C. $\mathrm{TiO}_{2} /$ nanoclay nanocomposite for phenol degradation in sonophotocatalytic reactor. The Canadian Journal of Chemical Engineering, 2012, vol. 90, pp. 1153-1159.

7. Singh V.R., Bagal M.V., Mota R.P. Phenolic wastewater treatment: a review. International Journal of Advance Engineering and Research Development, 2018, vol. 5, no. 5, article no. 15994.

8. Karamah E.F., Tjahjadi L., Bismo S., Purwanto W.W., Degradation of phenol by combination of ozonation and cavitation. Proceeding of the $12^{\text {th }}$ International conference on $Q i R$ (Quality in Research). Indonesia, Bali, 2011, pp. 119-126.

9. Bapat P.S., Gogate P.R., Pandit A.B. Theoretical analysis of sonochemical degradation of phenol and its chloro-derivatives. Ultrasonics Sonochemistry, 2008, vol. 15, pp. 564-570.

10. Bi Y.-G., Zheng Y.-H., Zhou S.-Q., Study on the process of degradation of phenolic compounds water by slot ultrasonic. E3S Web of Conferences: $4^{\text {th }}$ International conference on advances in energy and environment research (ICAEER), 2019, vol. 118, article no. 03050 .

11. Saksono N., Seratri R.T., Muthia R., Bismo S. Phenol degradation in wastewater with a contact glow discharge electrolysis reactor using a sodium sulfate. International Journal of Technology, 2015, vol. 6, no. 7, pp. 1153-1163.

12. Klymenko I., Yelatontsev D., Ivanchenko A., Dupenko O., Voloshyn M. Developing of effective treatment technology of the phenolic wastewater. Eastern-European Journal of Enterprise Technologies, 2016, vol. 3, no. 10(81), pp. 29-34.

13. Gogate P.R. Treatment of wastewater streams containing phenolic compounds using hybrid techniques based on cavitation: a review of the current status and the way forward. Ultrasonics Sonochemistry, 2008, vol. 15, pp. 1-15.

14. Kidak R., Ince N.H. Catalysis of advanced oxidation reactions by ultrasound: a case study with phenol. Journal of Hazardous Materials, 2007, vol. 146, pp. 630-635.

15. Lu Y., Liu Y., Xia B., Zuo W. Phenol oxidation by combined cavitation water jet and hydrogen peroxide. Chinese Journal of Chemical Engineering, 2012, vol. 20, pp. 760-767.

16. Mahamuni N.N., Pandit A.B. Effect of additives on ultrasonic degradation of phenol. Ultrasonics Sonochemistry, 2006, vol. 13, pp. 165-174.

17. Sivasankar T., Moholkar V.S. Mechanistic features of the sonochemical degradation of organic pollutants. AIChE Journal, 2008, vol. 54, pp. 2206-2219.

18. Sivasankar T., Moholkar V.S. Physical insights into the sonochemical degradation of recalcitrant organic pollutants with cavitation bubble dynamics. Ultrasonics Sonochemistry, 2009, vol. 16 , pp. 769-781.

19. Sivasankar T., Moholkar V.S. Mechanistic approach to intensification of sonochemical degradation of phenol. Chemical Engineering Journal, 2009, vol. 149, pp. 57-69. 
20. Chiha M., Merouani S., Hamdaoui O., Baup S., Gondrexon N., Petrier C. Modeling of ultrasonic degradation of non-volatile organic compounds by Langmuir-type kinetics. Ultrasonics Sonochemistry, 2010, vol. 17, pp. 773-782.

21. Serpone N., Terzian R., Colarusso P., Minero C., Pelizzetti E., Hidaka H. Sonochemical oxidation of phenol and three of its intermediate products in aqueous media: catechol, hydroquinone, and benzoquinone. Kinetic and mechanistic aspects. Research on Chemical Intermediates, 1993, vol. 18, pp. 183-202.

22. Petrier C., Francony A. Ultrasonic waste-water treatment: incidence of ultrasonic frequency on the rate of phenol and carbon tetrachloride degradation. Ultrasonics Sonochemistry, 1997, vol. 4, pp. 295-300.

23. Lesko T., Colussi A.J., Hoffmann M.R. Sonochemical decomposition of phenol: evidence for a synergistic effect of ozone and ultrasound for the elimination of total organic carbon from water. Environmental Science \& Technology, 2006, vol. 40, pp. 6818-6823.

24. Okouchi S., Nojima O., Arai T. Cavitation-induced degradation of phenol by ultrasound. Water Science and Technology, 1992, vol. 26, pp. 2053-2056.

25. Petrier C., Francony A. Incidence of wave-frequency on the reaction rates during ultrasonic wastewater treatment. Water Science and Technology, 1997, vol. 35, pp. 175-180.

26. Znak Z.O., Sukhatskiy Yu.V., Mnykh R.V., Tkach Z.S. Termokhimichnyi analiz energetyky protsessu sonolizu vody $u$ kavitatsiinykh polyakh [Thermochemical analysis of energetic in the process of water sonolysis in cavitation fields]. Voprosy Khimii i Khimicheskoi Tekhnologii, 2018, no. 3, pp. 64-69. (in Ukrainian).

27. Merouani S., Hamdaoui O., Rezgui Y., Guemini M. Mechanism of the sonochemical production of hydrogen. International Journal of Hydrogen Energy, 2015, vol. 40, pp. 40564064.

28. Znak Z.O., Sukhatskiy Yu.V., Zin O.I., Khomyak S.V., Mnykh R.V., Lysenko A.V. Rozklad benzolu v kavitatsiinykh polyakh [The decomposition of the benzene in cavitation fields]. Voprosy Khimii i Khimicheskoi Tekhnologii, 2018, no. 1, pp. 7277. (in Ukrainian).

29. Znak Z.O., Sukhatskiy Yu.V., Zin O.I., Vyrsta K.R. Intensyfikatsiya kavitatsiinogo rozkladu benzenu [The intensification of the cavitation decomposition of benzene]. Voprosy Khimii i Khimicheskoi Tekhnologii, 2019, no. 4, pp. 5561. (in Ukrainian).

30. Gogate P.R., Pandit A.B. Sonophotocatalytic reactors for wastewater treatment: a critical review. AIChE Journal, 2004, vol. 50, pp. 1051-1079.

31. Kim K., Cho E., Thokchom B., Cui M., Jang M., Khim J. Synergistic sonoelectrochemical removal of substituted phenols: implications of ultrasonic parameters and physicochemical properties. Ultrasonics Sonochemistry, 2015, vol. 24, pp. 172-177.
32. Timofeyeva S.S., Batoyeva A.A. Stochnye vody predpriyatii po dobyche i pererabotke rudnogo zolota $\mathrm{i}$ kombinirovannye tekhnologii ikh obezvrezhivaniya [Wastewater of enterprises for the extraction and processing of ore gold and combined technologies for their disposal]. Vestnik IrGTU, 2013, no. 11 (82), pp. 132-142. (in Russian).

33. Deng J. Study of porous plate hydrodynamic cavitation device for p-nitrophenol. Advanced Materials Research, 2014, vol. 1015 , pp. $385-388$.

34. Marwan M. Kinetics of phenol degradation in aqueous solution oxidized under low frequency ultrasonic irradiation. Jurnal Rekayasa Kimia \& Lingkungan, 2014, vol. 10, no. 1, pp. 34-39.

35. Her N.-G., Park J.-S., Oh J., Yoon Y. New design approaches for ultrasonic reactors: degradation of naphthalene and phenol in water. Water, Air, \& Soil Pollution, 2011, vol. 220, pp. $173-180$

36. Lu G., Zhao L., Zhu M., Deng C., Liu H., Ma J., Li Y. Effect of cavitation hydrodynamic parameters on bisphenol A removal. Environmental Engineering Science, 2019, vol. 36, no. 8 , pp. $873-882$.

37. Wu C.D., Zhang Z.L., Wu Y., Wang L., Chen L.J. Effects of operating parameters and additives on degradation of phenol in water by the combination of $\mathrm{H}_{2} \mathrm{O}_{2}$ and hydrodynamic cavitation. Desalination and Water Treatment, 2015, vol. 53, pp. $462-468$.

38. Znak Z., Sukhatskiy Yu. The Brandon method in modelling the cavitation processing of aqueous media. EasternEuropean Journal of Enterprise Technologies, 2016, vol. 3, no.8 (81), pp. 37-42.

39. Yavors'kyi V.T., Znak Z.O., Sukhats'kyi Yu.V., Mnykh R.V. Energy characteristics of treatment of corrosive aqueous media in hydrodynamic cavitators. Materials Science, 2017, vol. 52, pp. 595-600.

40. Yavorskiy V., Sukhatskiy Y., Znak Z., Mnykh R. Investigations of cavitation processes in different types of emitters using sonochemical analysis. Chemistry \& Chemical Technology, 2016, vol. 10, pp. 507-513.

41. Gogate P.R., Pandit A.B. A review of imperative technologies for wastewater treatment I: oxidation technologies at ambient conditions. Advances in Environmental Research, 2004, vol. 8, pp. 501-551.

42. Sivasankar T., Moholkar V.S. Physical insight into the sonochemical degradation of 2,4-dichlorophenol. Environmental Technology, 2010, vol. 31, pp. 1483-1494.

43. Drijvers D., van Langenhove H., Beckers M. Decomposition of phenol and trichloroethylene by the ultrasound/ $\mathrm{H}_{2} \mathrm{O}_{2} / \mathrm{CuO}$ process. Water Research, 1999, vol. 33, pp. 11871194.

44. Wu J., Jia R., Liu C., Wang H. Study of degradation of phenol in waste water sample via advanced oxidation technology. Proceedings of the 2015 International Forum on Energy, Environment Science and Materials (IFEESM 2015). 2015, pp. 584-587. 
45. Gagol M., Przyjazny A., Boczkaj G. Highly effective degradation of selected groups of organic compounds by cavitation based AOPs under basic $\mathrm{pH}$ conditions. Ultrasonics Sonochemistry, 2018, vol. 45, pp. 257-266.

46. Lu X., Zhao J., Wang Q., Wang D., Xu H., Ma J., Qiu W., Hu T. Sonolytic degradation of bisphenol S: effect of dissolved oxygen and peroxydisulfate, oxidation products and acute toxicity. Water Research, 2019, vol. 165, article no. 114969.

47. Gagol M., Przyjazny A., Boczkaj G. Wastewater treatment by means of advanced oxidation processes based on cavitation - a review. Chemical Engineering Journal, 2018, vol. 338 , pp. 599-627.

48. Chakma S., Moholkar V.S. Intensification of wastewater treatment using sono-hybrid processes: an overview of mechanistic synergism. Indian Chemical Engineer, 2015, vol. 57, pp. 359-381.

49. ElShafei G.M.S., Yehia F.Z., Eshaq Gh., ElMetwally A.E. Enhanced degradation of nonylphenol at neutral $\mathrm{pH}$ by ultrasonic assisted-heterogeneous Fenton using nano zero valent metals. Separation and Purification Technology, 2017, vol. 178, pp. 122-129.

50. Li X., Zhang Y., Xie Y., Zeng Y., Li P., Xie T., Wang Y. Ultrasonic-enhanced Fenton-like degradation of bisphenol A using a bio-synthesized schwertmannite catalyst. Journal of Hazardous Materials, 2018, vol. 344, pp. 689-697.

51. Molina R., Martinez F., Melero J.A., Bremner D.H., Chakinala A.G. Mineralization of phenol by a heterogeneous ultrasound/Fe-SBA- $15 / \mathrm{H}_{2} \mathrm{O}_{2}$ process: multivariate study by factorial design of experiments. Applied Catalysis B: Environmental, 2006, vol. 66, pp. 198-207.

52. Segura Y., Molina R., Martinez F., Melero J.A. Integrated heterogeneous sono-photo Fenton processes for the degradation of phenolic aqueous solutions. Ultrasonics Sonochemistry, 2009, vol. 16, pp. 417-424.

53. Zhou T., Lim T.T., Lu X., Li Y., Wong F.S Simultaneous degradation of 4CP and EDTA in a heterogeneous ultrasound/Fenton like system at ambient circumstance. Separation and Purification Technology, 2009, vol. 68, pp. 367-374.

54. Lim M., Son Y., Khim J. The effects of hydrogen peroxide on the sonochemical degradation of phenol and bisphenol A. Ultrasonics Sonochemistry, 2014, vol. 21, pp. 1976-1981.

55. Dutilleul H., Partaloglu A., da Costa P., Galvez M.E. Shock-induced cavitation as a way of accelerating phenol oxidation in aqueous media. Chemical Engineering and Processing: Process Intensification, 2017, vol. 112, pp. 47-55.

56. Thanekar P., Gogate P. Application of hydrodynamic cavitation reactors for treatment of wastewater containing organic pollutants: intensification using hybrid approaches. Fluids, 2018, vol. 3, article no. 98.
57. Tijani J.O., Fatoba O.O., Madzivire G., Petrik L.F. A review of combined advanced oxidation technologies for the removal of organic pollutants from water. Water, Air, \& Soil Pollution, 2014, vol. 225, article no. 2102.

58. Wu Z., Franke M., Ondruschka B., Zhang Y., Ren Y., Braeutigam P., Wang W. Enhanced effect of suction-cavitation on the ozonation of phenol. Journal of Hazardous Materials, 2011, vol. 190, pp. 375-380.

59. Chakinala A.G., Bremner D.H., Gogate P.R., Namkung K.C., Burgess A.E. Multivariate analysis of phenol mineralisation by combined hydrodynamic cavitation and heterogeneous advanced Fenton processing. Applied Catalysis B: Environmental, 2008, vol. 78, pp. 11-18.

60. Aseev D.G., Sizykh M.R., Batoeva A.A. Oxidative degradation of phenols in sono-Fenton-like systems upon highfrequency ultrasound irradiation. Russian Journal of Physical Chemistry A, 2017, vol. 91, pp. 2331-2336.

61. Khokhawala I.M., Gogate P.R. Degradation of phenol using a combination of ultrasonic and UV irradiations at pilot scale operation. Ultrasonics Sonochemistry, 2010, vol. 17, pp. 833838.

62. Joseph C.G., Puma G.L., Bono A., Krishnaiah D. Sonophotocatalysis in advanced oxidation process: a short review. Ultrasonics Sonochemistry, 2009, vol. 16, pp. 583-589.

63. Mahvi A.H. Application of ultrasonic technology for water and wastewater treatment. Iranian Journal of Public Health, 2009, vol. 38, no. 2, pp. 1-17.

64. Mahamuni N.N., Adewuyi Y.G. Advanced oxidation processes (AOPs) involving ultrasound for waste water treatment: a review with emphasis on cost estimation. Ultrasonics Sonochemistry, 2010, vol. 17, pp. 990-1003.

65. Papoutsakis S., Miralles-Cuevas S., Gondrexon N., Baup S., Malato S., Pulgarin C. Coupling between high-frequency ultrasound and solar photo-Fenton at pilot scale for the treatment of organic contaminants: an initial approach. Ultrasonics Sonochemistry, 2015, vol. 22, pp. 527-534.

66. Chen Y.C., Smirniotis P. Enhancement of photocatalytic degradation of phenol and chlorophenols by ultrasound. Industrial \& Engineering Chemistry Research, 2002, vol. 41 , pp. 5958-5965.

67. Trabelsi F., Ait-Lyazidi H., Ratsimba B., Wilhelm A.M., Delmas H., Fabre P.L., Berlan J. Oxidation of phenol in wastewater by sonoelectrochemistry. Chemical Engineering Science, 1996, vol. 51, pp. 1857-1865.

68. Entezari M.H., Petrier C. A combination of ultrasound and oxidative enzyme: sono-enzyme degradation of phenols in a mixture. Ultrasonics Sonochemistry, 2005, vol. 12, pp. 283-288. 